\title{
High-flow nasal cannula versus noninvasive positive pressure ventilation in acute respiratory failure: interaction between $\mathrm{PaO}_{2} / \mathrm{FiO}_{2}$ and tidal volume
}

\author{
Yanfei Shen ${ }^{1 *}$ (D) and Weimin Zhang ${ }^{2}$
}

See related research by Zhao et al., https://ccforum.biomedcentral.com/articles/10.1186/s13054-017-1760-8

We read with interest the systematic review by Zhao et al. [1] comparing the effect of the high-flow nasal cannula (HFNC) and noninvasive positive pressure ventilation (NIPPV) therapies in acute respiratory failure. Coincidentally, a similar review [2] was also published in Chest recently in which the cohort studies were also included. Both of these two reviews reported that, compared to HFNC, NIPPV had a similar endotracheal intubation rate in acute respiratory failure. However, the heterogeneity was significant ( $\mathrm{I} 2=53 / 63 \%)$.

Despite the statistical approach being appropriate, we believe this heterogeneity could be partly explained by the interactive effect between the $\mathrm{PaO}_{2} / \mathrm{FIO}_{2}$ and tidal volume. Simply using a random-effect model may lead to a biased conclusion.

Six studies were included in Figure 5 of $\mathrm{Ni}$ et al.'s study [2]. We noticed that the mean baseline $\mathrm{PaO}_{2} / \mathrm{FiO}_{2}$ among these studies was largely different: in three studies (PMID 27207177, 25981908, 26106206) it was around $150 \mathrm{mmHg}(144,145$, and $153 \mathrm{mmHg}$, respectively) and in the other three (PMID 27706464, $25980660,26767861)$ it was around $200 \mathrm{mmHg}(189$, 192, and $199 \mathrm{mmHg}$, respectively). We performed a subgroup meta-analysis (Fig. 1) according to the $\mathrm{PaO}_{2} / \mathrm{FiO}_{2}$ levels and found that, compared to NIPPV, HFNC was associated with lower intubation rates (odds ratio (OR)
0.48; 95\% confidence interval (CI) 0.31-0.73) in patients with low baseline $\mathrm{PaO}_{2} / \mathrm{FiO}_{2}$, while with high baseline $\mathrm{PaO}_{2} / \mathrm{FiO}_{2}$, the comparison was insignificant (OR 1.07; 95\% CI 0.82-1.40). Besides, the heterogeneity became insignificant in these two subgroups.

The mechanism cannot be inferred from this review. Studies have indicated that lung protective ventilation during NIPPV was as important as it was during invasive mechanical ventilation in respiratory failure [3]. However, strategies such as using low tidal volumes are unlikely to work under NIPPV treatment [4] and, compared to HFNC, NIPPV was associated with higher tidal volumes, which was strongly associated with ventilator-induced lung injury.

Thus, we speculated that, in patients with low baseline $\mathrm{PaO}_{2} / \mathrm{FiO}_{2}$ (which to some extent indicate more severe lung injury), high tidal volume-related ventilationinduced lung injury (VILI) was more likely to happen under NIPPV therapy. Yet, both NIPPV and HFNC were still suitable for patients with mild lung injury (high $\mathrm{PaO}_{2} / \mathrm{FiO}_{2}$ level). This finding suggests an interactive role of $\mathrm{PaO}_{2} / \mathrm{FiO}_{2}$ with NIPPV and the importance of proper patient selection before NIPPV treatment. Further studies are needed to explore which acute respiratory failure patients are good candidates for NIPPV support.

\footnotetext{
* Correspondence: snow.shen@hotmail.com

${ }^{1}$ Intensive care unit, Dongyang People's Hospital, NO.60 wuning west Road,

Jinhua City, Zhejiang 322100, People's Republic of China

Full list of author information is available at the end of the article
} 


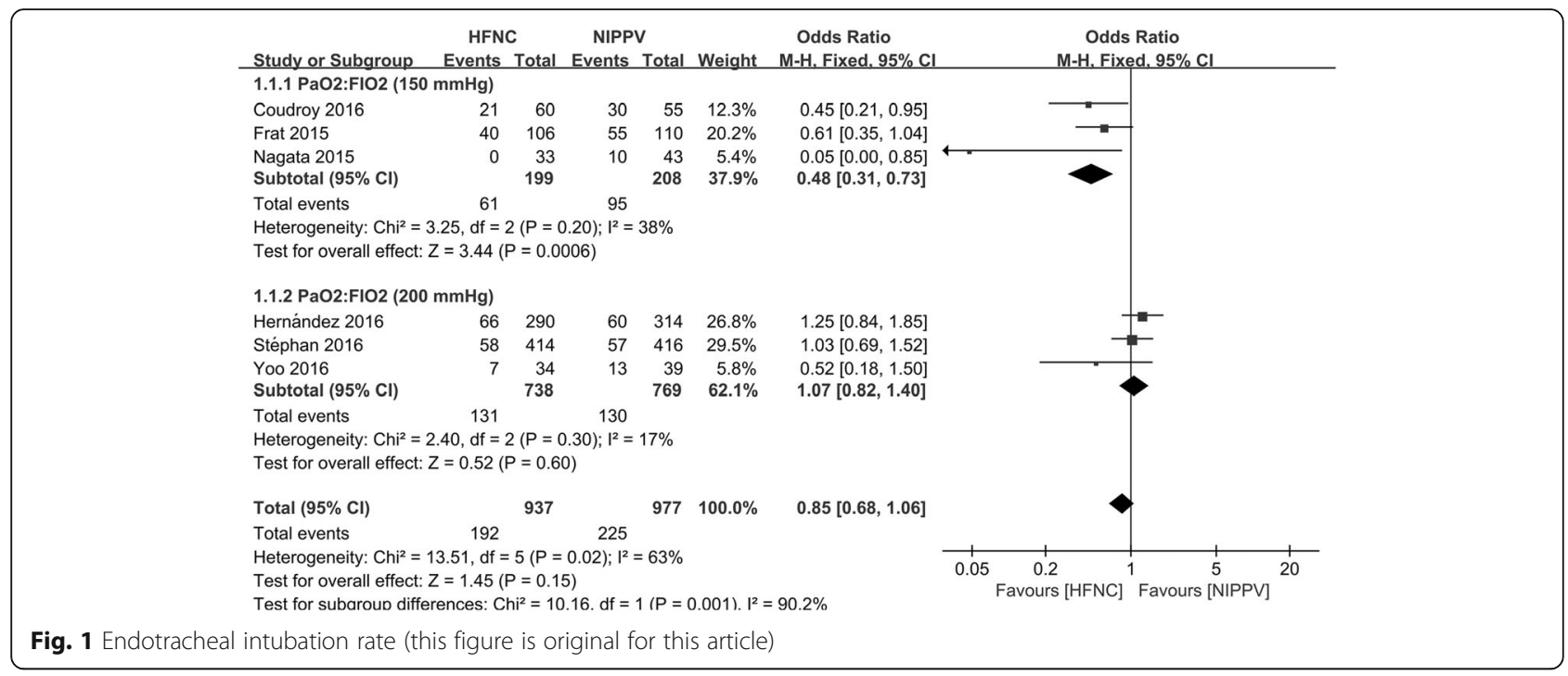

\section{Acknowledgements}

None.

\section{Funding}

None.

Availability of data and material

Not applicable.

\section{Authors' contributions}

YS came up with the questions and WZ is responsible for writing. Both authors read and approved the final manuscript.

\section{Ethics approval and consent to participate}

Not applicable.

\section{Consent for publication}

Not applicable.

\section{Competing interests}

The authors declare that they have no competing interests.

\section{Publisher's Note}

Springer Nature remains neutral with regard to jurisdictional claims in published maps and institutional affiliations.

\section{Author details}

'Intensive care unit, Dongyang People's Hospital, NO.60 wuning west Road, Jinhua City, Zhejiang 322100, People's Republic of China. ${ }^{2}$ Department of Intensive care unit, Dongyang People's Hospital, NO.60 wuning west Road, dongyang, Jinhua, Zhejiang 322100, People's Republic of China.

Received: 22 September 2017 Accepted: 12 October 2017

Published online: 22 November 2017

\section{References}

1. Zhao H, Wang H, Sun F, Lyu S, An Y. High-flow nasal cannula oxygen therapy is superior to conventional oxygen therapy but not to noninvasive mechanical ventilation on intubation rate: a systematic review and metaanalysis. Crit Care. 2017;21(1):184

2. Ni YN, Luo J, Yu H, Liu D, Ni Z, Cheng J, Liang BM, Liang ZA. Can high-flow nasal cannula reduce the rate of endotracheal intubation in adult patients with acute respiratory failure compared with conventional oxygen therapy and noninvasive positive pressure ventilation? A systematic review and meta-analysis. Chest. 2017;151(4):764-75.
3. Patel BK, Wolfe KS, Pohlman AS, Hall JB, Kress JP. Effect of noninvasive ventilation delivered by helmet vs face mask on the rate of endotracheal intubation in patients with acute respiratory distress syndrome: a randomized clinical trial. JAMA. 2016;315(22):2435-41.

4. Carteaux G, Millan-Guilarte T, De Prost N, Razazi K, Abid S, Thille AW, Schortgen F, Brochard L, Brun-Buisson C, Mekontso DA. Failure of noninvasive ventilation for de novo acute hypoxemic respiratory failure: role of tidal volume. Crit Care Med. 2016;44(2):282-90.

Submit your next manuscript to BioMed Central and we will help you at every step:

- We accept pre-submission inquiries

- Our selector tool helps you to find the most relevant journal

- We provide round the clock customer support

- Convenient online submission

- Thorough peer review

- Inclusion in PubMed and all major indexing services

- Maximum visibility for your research

Submit your manuscript at www.biomedcentral.com/submit
Biomed Central 